\title{
Efficacy of animal origin products and ajwain powder against honey bee diseases in Apis mellifera (Linnaeus) colonies in Uttarakhand-A novel eco-friendly approach
}

\author{
Ruchira Tiwari*, Meena Dhami, Vaibhav Mathur and Brijesh Bisht \\ Department of Entomology, College of Agriculture, G. B. Pant University of Agriculture and Technology \\ Pantnagar, Distt. Udham Singh Nagar (Uttarakhand) INDIA \\ *Corresponding author. E-mail: ruchis03@rediffmail.com
}

Received: January 12, 2014; Revised received:March 12,2014; Accepted: March 20, 2014

\begin{abstract}
The studies to manage the honey bee bacterial European foul brood (EFB) disease caused by Melisococcus plutonius and ectoparasitic brood mite disease caused by Varroa destructor in the colonies of Apis mellifera (L.) at different locations of Uttarakhand were conducted during 2012- 2013 by applying eco-friendly formulations i.e. spraying of cow urine (desi cow breed), plant decoctions prepared in cow urine, cow dung cake and cow dung ash powders, ajwain seed powder and compared to an antibiotic, terramycin sugar syrup and synthetic chemicals, sulphur and thymol powder with two applications in a month. The data revealed that the cow urine sprays @ 50, 75 and 100\% reduced the disease infection to below detectable limit in 10 to 14 days, respectively, as terramycin treated infected colonies where only $50-55 \%$ recovery was seen in EFB infection with highest sealed worker brood areas ( SWBA) in cow urine treated honeybee colonies in comparison to terramycin and untreated colonies. Similarly, on the other hand, cow urine (100\%) significantly reduced brood mite infestation $(72.10 \%)$ with highest mean mite fall (48.73) and highest (SWBA) $\left(854.00 \mathrm{~cm}^{2}\right)$ followed by ajwain powder with reduction in brood mite infestation(65.84\%) with mite fall (46.39) and SWBA $\left(749.00 \mathrm{~cm}^{2}\right)$, cow dung powder with reduction in brood mite infestation (71.35\%), mite fall ( 42.87$)$, SWBA $\left(682.33 \mathrm{~cm}^{2}\right)$, , followed by cow dung ash powder, cow urine @ 25\%, in comparison to plant decoctions prepared in cow urine, synthetic chemicals i.e. thymol and sulphur powder after 4 weeks of treatments. Thus, the animal origin products and ajwain powder can serve as a potential eco- friendly measure for management of honeybee diseases in $A$. mellifera colonies at different locations of Uttarakhand as they significantly increased sealed worker brood area without affecting the activities of workers, queen bee and bee brood in comparison to chemicals and plant decoctions.
\end{abstract}

Keywords: Animal origin products, Ajwain, Bacterial disease, Cow urine, Honey bee, Varroa mite

\section{INTRODUCTION}

The European honeybee, Apis mellifera (L.) (Hymenoptera: Apidae) is economically important (Williams and Carreck, 1994), primarily because of its role in the pollination of many agricultural and horticultural crops. Honey bees are the best known and most useful insects, not only for the production of honey and other valued hive products such as bees wax, bee venom, propolis and royal jelly, but also for their more important role as the efficient pollinators of flowering crops and trees, which leads to enhanced crop productivity, besides contributing to the maintenance of plant diversity. The European honey bee, A. mellifera (Linnaeus), an exotic species, has adapted to different climates, is widely domesticated in the plains of Uttarakhand.

Diseases of bee are the serious problems which in turn cause economic losses to beekeepers and further hamper the expansion of beekeeping and the bee industry worldwide. European foulbrood (EFB) is a brood disease caused by the bacteria, Melissococcus reproduction and are well protected
ISSN : 0974-9411 (Print), 2231-5209 (Online) All Rights Reserved $\odot$ Applied and Natural Science Foundation www.ansfoundation.org plutonius (Shimanuki and Knox, 1997). It is a gram positive, non-spore forming, rod like bacterium. The antibiotics like terramycin, oxytetracycline etc. are mainly used to control EFB are mixed with powdered sugar and fed to bees (Sanjaram and Rana, 2006). But, the development of resistance to terramycin and contamination of honey due to antibiotics has led to a ban on this drug (Miyagi et al., 2000). Use of pesticides such as residues of organophosphates compounds and organochlorines were found in honey (Khan et al., 2004) and pollen (Chauzet et al., 2006) also cause ill effects on honeybee, bee products and mankind (Dhaliwal and Singh, 2000).

The honey bee mite, Varroa destructor (Anderson and Trueman, 2000) is an ectoparasite of the Asian honey bee (Apis cerana) that has become potentially the main parasite of A. mellifera in the last few decades (De Jong, 1990). The mite infests the bees by entering into the brood cells before capping and parasitizing honey bee larvae and pupae and its control becomes difficult as majority of the mites stay in the sealed brood for reproduction and are well protected from the chemical 
treatments (Harold et al., 1989).

Several chemical substances have been used successfully to control mites, in recent years; resistance to acaricides has become a major problem in the control of varroa. Varroa destructor strains have been reported to be resistant to fluvalinate and flumethrin (Baxter et al. 1998), coumaphos (Spreafico et al. (2001). Also, the use of acaricides should be minimized in beekeeping because of the residues and their breakdown products in honey and wax (Wallner, 1999). Natural products having components with various modes of action might provide effective solution to the problem of varroatosis (Imdorf et al. 1999). The natural product such as citric acid was less toxic to varroa than oxalic acid (Milani, 2001). Also, grapefruit oil (Elzen et al., 2000), and lemongrass oil were used for controlling varroa mites (Fathy and Fouly, 1995).

The synthetic chemical thymol (also known as 2-isopropyl-5-methylphenol, IPMP) is a natural monoterpene phenol found in oil of thyme, and extracted from Thymus vulgaris (common thyme) and Ajwain (Trachyspermum ammi. Syn. Carum copticum) a white crystalline substance of a pleasant aromatic odor and strong antiseptic properties. $\mathrm{Hu}$ and Coats (2008) observed that thymol can be successfully used to control varroa mites and prevent fermentation and the growth of mold in bee colonies, but with adverse effect on brood, worker bees and queen bee. Therefore, in the present studies, the efficacy of synthetic chemical thymol was compared with cow urine and naturally occurred thymol in plant product, ajwain seed powder so that chemical thymol can be replaced by the natural product, ajwain powder.

To reduce the ill effects of chemicals on honeybees, it is the need of time to re-evaluate the efficacy of traditional methods to control insect pests and diseases for better production of honey by increasing the resistance power in honeybees. Out of the many non-synthetic insecticidal control methods of diseases, uses of animal and plant originated products are gaining more attention.

However, it was a novel approach to use animal waste products i.e. cow urine, cow dung cake powder, cow dung ash powder, and cow urine plant decoctions in honey bee disease management in Uttarakhand. The present study therefore, deals with the impact of natural products such as animal origin product, cow urine and plant products in controlling bacterial disease, EFB and honeybee mite in A. mellifera colonies in Uttarakhand.

\section{MATERIALS AND METHODS}

To study about the efficacy of cow urine against the honey bee bacterial disease, EFB at different locations in Uttrakhand (under Tarai and Bhabhar regions) have been surveyed to find out the incidence of EFB in A. mellifera colonies in the year 2012-13. Under Bhabhar region, the experiments were conducted at Haldwani. whereas in Tarai region, the experiments were done at Halduchaur and Dineshpur at apiaries of different beekeepers.

Field experiments: The field experiments were conducted in honey bee, A. mellifera colonies reared in Langstroth size beehive having 5-6 frames strength. The experimental colonies were naturally infected with European foulbrood (EFB) disease and no hard chemicals were used in these colonies. The field experiments were conducted in months of May- July in the years 2012-2013 during the appearance of the disease in the colonies of A. mellifera at Dineshpur, Halduchaur and Haldwani in Uttarakhand. Two sprayings of cow urine 10-15ml (@25\%,50\%,75\% and $100 \%)$ per replication and terramycin sugar syrup (125 $\mathrm{mg} / \mathrm{lt}$ sugar syrup/colony), respectively, were carried out on the selected and marked highly infected area $\left(100 \mathrm{~cm}^{2}\right)$ (taken as $100 \%$ infection) in triplicate with the help of plastic sprayer (applied gently on the infected brood) after the interval of 7 days whereas two feedings of terramycin sugar syrup $(125 \mathrm{mg} / \mathrm{lt} /$ colony) were given to the infected colony. Second feeding of terramycin sugar syrup was done after 7 days of first feeding.

The recovery in infection was calculated by the formula:

$\%$ recovery of infection $=($ No. of recovered cells after spraying/ Total number of infected cells) x 100

Observations were recorded on EFB-infection level on 7 days after first and second spraying of different treatments.

Field experiments on mite infestation in honey bee colonies at different locations in Uttarakhand: The experiments were conducted in the honeybee colonies of A. mellifera at the apiary sites at Dineshpur, Halduchaur and Haldwani in 3 replications during July -August 2012 and 2013. The honey bee colonies used in the studies were with young prolific queens which were free from diseases. The bee colonies were of equal strength (5-6 bee frames) in respect of brood, hive stores and adult bee population in Langstroth hives. The experimental colonies were naturally infected with mite, Varroa destructor. Use of eco-friendly formulations along with synthetic chemicals i.e. thymol powder and sulphur dust were applied separately in infested bee colonies and data were collected.

Extraction of bioactive compounds: The test plants, leaves and seeds of neem, (Azardiracta indica L.) and Jatropha (Jatropha curcas L.) were collected from the University campus and nearby areas of Pantnagar, whereas, Ajwain seeds (Trachyspermum ammi. Syn. Carum copticum) were purchased from local market and the animal origin products i.e. cow urine and cow dung cake were collected from Desi cow breed. The cow dung cake was burnt to get cow dung ash powder. To prepare plant decoctions in cow urine, leaves of neem and jatropha were first washed with water to 
remove the dust particles or foreign matter, dried in shade just to remove water intact with leaves during wash. To prepare $2 \%$ and $5 \%$ concentrations, 20 and 50 grams of leaves and seed powders of neem and jatropha were weighed separately by using a top balance, macerated in the electrical grinder and dipped in $1000 \mathrm{ml}$ of cow urine in the containers and were kept for fermentation for $24 \mathrm{hrs}$ and then filter by using muslin cloth.

Mode of application of treatments: Spraying of cow urine and cow urine plant extracts were conducted by using plastic sprayer (Flit pump) as follows:

-Spraying of cow urine 10-15 ml/bee frame @ $25 \%$ and $100 \%$.

-Spraying of plant decoctions prepared in cow urine @ 2\% and 5\% (10-15 ml/ bee frame).

- Powders of ajwain seeds, cow dung cake and cow dung ash @ 5g/hive were dusted in between the frames.

-Thymol powder @ 500 mg/hive was kept on the bottom board.

-Sulphur dust/powder @ 100 mg/colony was dusted in between the frames in the colonies.

-Control -no chemical agent was used.

Efficiency of different formulations was measured using the following parameters:

Infestation per cent: Extent of damage was worked out by recording data on per cent brood infestation, which was determined by randomly opening of 50 brood capping per colony for the presence of mites (different stages). The per cent brood infestation was calculated by the formula:

Per cent brood Infestation $=($ No. of cells with mites $/$ Total no. of cells observed) X 100

Evaluation of the tested materials and techniques were based on the efficiency (\%) and was evaluated according to Henderson and Tilton (1955) equation:

$\%$ Reduction of infestation $=100 \times 1-\{\mathrm{Ta} \times \mathrm{Cb}\} /$ $\{\mathrm{Tb} \times \mathrm{Ca}\}$

Where, $\mathrm{T}=\%$ infestation of treated mites and $\mathrm{C}=\%$ infestation of untreated mites $(\mathrm{a}=$ after; $\mathrm{b}=$ before treatment).

Mite fall: Counts of dropped mites were recorded before and after 1 day, 1 week to 4 weeks of the application using plastic sheets $(51.5 \times 36.5 \mathrm{~cm})$ coated with vaseline placed on the hive bottom board.

Brood measurement: Sealed worker brood areas (SWBA) were recorded at 15-day intervals using a plastic sheet divided into square inches, converted $\mathrm{cm}^{2}$ when multiplied by 2.54 . Observations were taken for 4 weeks, before and after second application of the treatments on $15^{\text {th }}$ day of the first application.

The data on EFB infection and mite infestation, mite fall and SWBA were subjected to RBD (two factorial) after suitable transformations using programme STPR3.

\section{RESULTS AND DISCUSSION}

Effect of cow urine and antibiotic on per cent infection/ recovery of EFB disease: The compiled mean data on EFB infection at three locations i.e.
Dineshpur, Haldwani and Halduchaur is presented in (Table 1) clearly showed the effect of cow urine at different concentrations in comparison to antibiotic, terramycin and untreated control. It has been observed that after 7 days of first spraying of cow urine @ $100 \%$, the mean per cent infection of EFB was decreased to 27.66 followed by cow urine @ $75 \%$ $(57.45 \%)$, cow urine $50 \%(68.44 \%)$, terramycin spraying $(60.55 \%)$, cow urine @ 25\% (71.89\%) and terramycin feeding $(70.89 \%)$. The EFB infection was significantly reduced after 7 days of $\mathrm{II}^{\text {nd }}$ spraying of cow urine @ 100\% (0.00\%) with cent per cent recovery in infection followed by cow urine $75 \%$ with infection (9.77\%), cow urine @ 50\% (17.55\%) and cow urine@25\% (20.78\%) which was significantly less than EFB infection found in terramycin spraying $(44.77 \%)$ and teraamyci feeding $(43.33 \%)$. It has been observed that the cow urine spray significantly reduced the disease infection in 14-15 days as compared to terramycin treated infected colonies. In cow urine sprayed colonies 79.22 to $100 \%$ recovery has been recorded, whereas, in terramycin treatment only 55.33$56.67 \%$ recovery in EFB infection was observed at three different locations of Uttarakhand.

Effect of cow urine on sealed worker brood areas: It was prominently noticed that after spraying cow urine on the infected bee frames, the worker bees became active to clean the infected cells with throwing out of the infected bee larvae from the colonies and queen bee laid healthy eggs in those cleaned cells which hatched out normally. On this basis the sealed worker brood areas (SWBA in $\mathrm{cm}^{2}$ ) were calculated and highly significant difference was found among the treatments. In cow urine @ 100\% spray SWBA was significantly higher $\left(912.73 \mathrm{~cm}^{2}\right)$ followed by cow urine @755 (819.01 cm $\left.\mathrm{cm}^{2}\right)$, cow urine 50\% (645.57 $\left.\mathrm{cm}^{2}\right)$, cow urine $25 \%\left(598.14 \mathrm{~cm}^{2}\right)$ in comparison to terramycin spraying $\left(462.21 \mathrm{~cm}^{2}\right)$, terramycin feeding $\left(421.63 \mathrm{~cm}^{2}\right)$ and untreated control $\left(244.37 \mathrm{~cm}^{2}\right)$. Cow urine treated infected combs not only showed rapid recovery in disease infection but also promotion of growth of brood. The worker bees worked efficiently and cleaned the infected brood area and other bees in the colonies. The healthy brood area which was free from EFB-infection was however, remained healthy in all the cow urine treatments and the healthy brood which was sprayed with cow urine were also found healthy and developed into fully developed adults. The present studies revealed that the cow urine can serve as a potential eco- friendly measure for management of EFB in honeybee colonies in Uttarakhand.

Effect of eco-friendly formulations on brood mite infestation: The compiled mean data of on per cent brood mite infestation of all three apiary sites at Dineshpur, Halduchaur and Haldwani in Uttarakhand is presented in (Table 2) clearly showed that cow urine $100 \%$, significantly reduced brood mite infestation (72.10\%) from 32.00 per cent before application to 
Ruchira Tiwari et al. / J. Appl. \& Nat. Sci. 6 (1): 68-75 (2014)

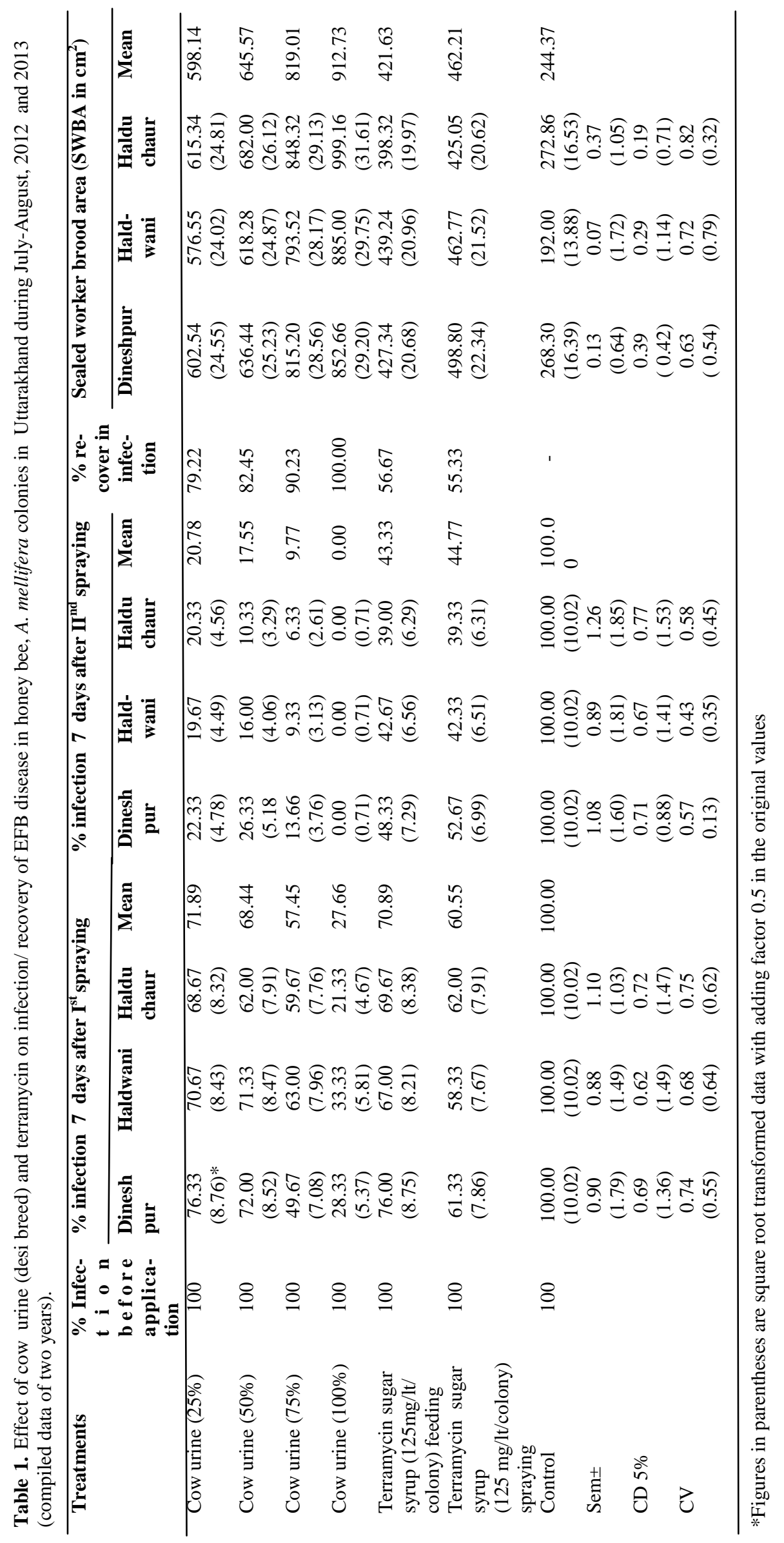


Table 2. Effect of eco-friendly formulations on mite brood infestation in A. mellifera colonies during July- August 2012 and 2013 (Compiled data for three apiary sites).

\begin{tabular}{|c|c|c|c|c|c|}
\hline \multirow[t]{2}{*}{ S. $\mathbf{N}$. } & \multirow[t]{2}{*}{ Treatments } & \multirow[t]{2}{*}{ Conc. } & \multicolumn{3}{|c|}{$\begin{array}{l}\text { Percent brood mite infestation } \\
\text { Mean of two years }(2012 \& 2013)\end{array}$} \\
\hline & & & Pretreatment & $\begin{array}{l}\text { Post Treatment } \\
\text { (After } 4 \text { weeks ) }\end{array}$ & $\begin{array}{l}\text { Per cent reduction in } \\
\text { brood mite }\end{array}$ \\
\hline 1. & Cow urine & $25 \%$ & $27.33(31.51)^{*}$ & $10.33(18.73)$ & 68.28 \\
\hline 2. & Cow urine & $100 \%$ & $32.00(34.45)$ & $10.67(19.05)$ & 72.10 \\
\hline 3. & $\begin{array}{l}\text { Neem Leaf Cow urine } \\
\text { Extract (NLCUE) }\end{array}$ & $2 \%$ & 29.67(32.99) & $22.33(28.19)$ & 36.90 \\
\hline 4. & $\begin{array}{l}\text { Neem Leaf Cow urine } \\
\text { Extract(NLCUE) }\end{array}$ & $5 \%$ & $27.33(31.51)$ & $20.00(26.57)$ & 38.60 \\
\hline 5. & $\begin{array}{l}\text { Jatropha Leaf Cow urine } \\
\text { Extract (JLCUE) }\end{array}$ & $2 \%$ & $28.67(32.36)$ & $22.33(28.20)$ & 34.70 \\
\hline 6. & $\begin{array}{l}\text { Jatropha leaf cow urine } \\
\text { Extract (JLCUE) }\end{array}$ & $5 \%$ & $25.33(30.21)$ & $19.00(25.84)$ & 37.10 \\
\hline 7. & $\begin{array}{l}\text { Neem Seed Cow urine } \\
\text { Extract(NSCUE) }\end{array}$ & $2 \%$ & $36.00(36.87)$ & $19.67(26.32)$ & 54.20 \\
\hline 8. & $\begin{array}{l}\text { Neem Seed cow urine } \\
\text { Extract (N SCUE) }\end{array}$ & $5 \%$ & $31.67(34.24)$ & $16.33(23.83)$ & 56.80 \\
\hline 9. & $\begin{array}{l}\text { Jatropha Seed Cow urine } \\
\text { Extract JSCUE) }\end{array}$ & $2 \%$ & $32.00(34.45)$ & $22.00(27.97)$ & 42.40 \\
\hline 10. & $\begin{array}{l}\text { Jatropha Seed cow urine } \\
\text { Extract (JSCUE) }\end{array}$ & $5 \%$ & $30.67(33.61)$ & $19.33(26.07)$ & 47.20 \\
\hline 11. & $\begin{array}{l}\text { Cow Dung Cake Powder } \\
\text { (CDP) }\end{array}$ & $5 \mathrm{~g}$ & $27.33(31.51)$ & $09.33(17.78)$ & 71.35 \\
\hline 12. & $\begin{array}{l}\text { Cow Dung Ash Powder } \\
\text { (CDAP) }\end{array}$ & $5 \mathrm{~g}$ & $29.33(32.78)$ & $10.67(19.05)$ & 69.47 \\
\hline 13. & Ajwain Powder (AP) & $5 \mathrm{~g}$ & $28.67(32.36)$ & $11.67(19.96)$ & 65.84 \\
\hline 14. & Thymol Powder (TP) & $500 \mathrm{mg}$ & $33.00(35.06)$ & $22.33(28.66)$ & 51.11 \\
\hline 15. & Sulphur Dust (S) & $100 \mathrm{mg}$ & $38.33(38.24)$ & $25.33(30.21)$ & 35.50 \\
\hline 16. & Control & - & $33.00(35.06)$ & $39.33(38.83)$ & - \\
\hline & Sem \pm & - & $0.14(0.16)$ & $(0.85)(0.53)$ & - \\
\hline & $\mathrm{CD} 5 \%$ & - & $0.41(0.47)$ & $(0.25)(0.15)$ & - \\
\hline & $\mathrm{Cv}$ & - & $0.80(0.84)$ & $(0.79)(0.37)$ & - \\
\hline
\end{tabular}

*Figures in the parentheses are angular transformed values.

10.67 per cent after 4 weeks of treatment followed by cow dung cake powder $(71.35 \%)$, cow dung ash powder $(69.47 \%)$, cow urine @ 25\% (68.28\%) and ajwain powder with $(65.84 \%)$ reduction in brood mite infestation in comparison to significantly less reduction in brood mite infestation in synthetic chemical treated bee colonies i.e. thymol powder $(51.11 \%)$ and sulphur $(35.50 \%)$. Among the plant decoctions sprayed on the mite infested bee combs, significantly less reduction in brood mite infestation was observed in treatments, NSCUE @ 5\% (56.80\%) followed by NSCUE@ @\% (54.20\%), JSCUE @ 5\% (47.20\%), JSCUE@2\% (42.40\%), NLCUE@5\% (38.60\%), JLCUE @\%\% (37.10\%), NLCUE @ 2\% (36.90\%), JLCUE @2\% (34.70\%) in comparison to the chemical, sulphur which gave only $35.50 \%$ in $A$. mellifera colonies.

Effect of treatments on mite fall: The mean number of fallen mites/ colony at all three apiary sites before and after treatment is averaged in (Table 3). After one week of spraying, cow urine @ 100\% showed the highest mean mite fall $(46.33 \%)$ followed by ajwain powder@5 g (44.33\%), cow dung ash powder@5g (40.00\%), cow dung cake @ 5g (38.33\%) and cow urine $25 \%(37.00 \%)$ in comparison to mean mite fall in synthetic chemicals, thymol powder @ $500 \mathrm{mg}$ $(36.33 \%)$ and sulphur powder@100 mg (31.67\%) with lowest mean mite fall in untreated control (1333 $\%)$. On the other hand, plant decoctions prepared in cow urine showed significantly less mite fall ranged from $24.67 \%$ to $36.67 \%$. The significantly highest mean mite fall was observed after 0ne month of application of treatments in cow urine @ $100 \%$ $(56.33 \%)$ followed by ajwain powder $(55.00 \%)$, cow dung cake powder $(52.67 \%)$. The total mean mite fall after one month was significantly more in cow urine @ $100 \%(48.73 \%)$ followed by ajwain powder @ $5 \mathrm{~g}$ (46.39\%), cow dung cake powder @5 g (42.87\%), cow urine @ $255(40.06 \%)$ and cow dung ash powder @ $5 \mathrm{~g}(39.87 \%)$ in comparison to total mean mite fall in chemical treated colonies, thymol powder @ 500mg $(38.19 \%)$ and sulphur @ $100 \mathrm{mg}(25.67 \%)$. Among the plant decoctions the total average mite fall was ranged between JLCUE@ 2\% (18.59\%) to NLCUE @5\% 
Ruchira Tiwari et al. / J. Appl. \& Nat. Sci. 6 (1): 68-75 (2014)

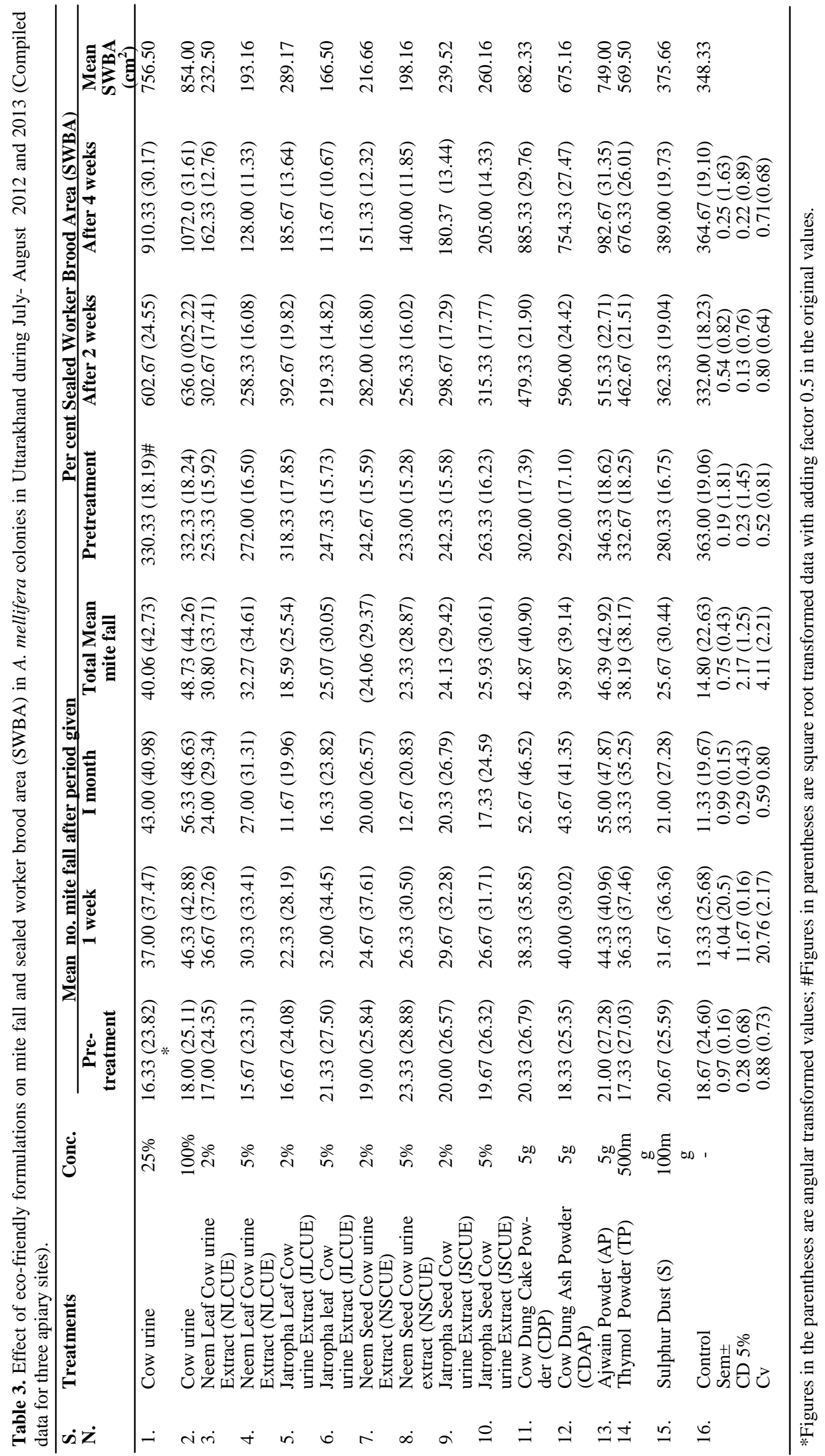


$(32.27 \%)$ with least mean mite fall in untreated control $(14.80 \%)$

Effect of treatments on brood rearing activity: The data presented in (Table 3) showed significant increase in average sealed worker brood area (SWBA in $\mathrm{cm}^{2}$ ) in the bee colonies given cow urine @ (100\%), cow urine @(25\%), ajwain powder, cow dung cake powder and cow dung ash powder with 854.00, 756.50,749. $00,682.33$ and $675.16 \mathrm{~cm}^{2}$, respectively after the end of 4 weeks (one month) of application in comparison to SWBA in synthetic chemical, thymol $\left(569.50 \mathrm{~cm}^{2}\right)$ and sulphur $\left(375.66 \mathrm{~cm}^{2}\right)$. It has been clearly noticed that the plant decoctions prepared in cow urine @ 2\% and $5 \%$ were limited the brood rearing activity of bees as the sealed worker brood areas started were ranged from $233.00 \mathrm{~cm}^{2}$ to $318.33 \mathrm{~cm}^{2}$ which was drastically reduced to $166.50 \mathrm{~cm}^{2}$ to 289.17 $\mathrm{cm}^{2}$ after 4 weeks of treatment with SWBA (348.33 $\mathrm{cm}^{2}$ ) in untreated control.

The decrease in SWBA in case of plant decoctions may be their noticeable adverse effect on brood rearing, queen loss, queen stopped egg laying and damaged brood. It has been noticed in bee colonies treated with plant decoctions that old brood was damaged and new brood was very less which was picked out by the worker bees. The newly laid eggs were not found indicated that egg laying tendency of queen bee was greatly affected. Due to which the strength of adult worker bees declined and finally the colonies collapsed after two months of applications of these formulations, whereas on the other hand powders of ajwain, cow dung cake and cow dung ash and cow urine were found significantly superior in reduction in mite brood infestation, highest mite fall and healthy normal and highest sealed worker brood areas with more honey and pollen stores. This indicated that the cow urine based plant decoctions were reduced the mite infestation in brood and gave average mite fall in the treated colonies but on the other hand the old and new brood was also greatly affected with adverse effect on worker bees, rearing activities and queen egg laying capacity with less honey and pollen stores in the colonies.

The effect of many plant products such as essential oils and extracts as acaricides in protecting varroa mite infestation has been studied, and it has been shown that this mite is susceptible to the some plant derived materials. Most of these extracts cause the mite to release from the bees, but do not cause mite mortality, and are therefore of limited value. These results are supported by the finding of Shoreit and Hussein (1994) who found that, the maximum mean number of dead mites was noticed after the first treatment with coriander extract in both of winter or spring feeding. Dimetry et al. (2005) found that neem oil spray killed 90 to $94 \%$ of varroa mites but thymol oil spray reduced Varroa mites to $79 \%$ in honey bee colonies. The studies on the volatile oils of basil, geranium and eugenol against Varroa mites in honeybee colonies in Egypt exhibited noticeable varroacidal activity with counts of dropped mites were also significantly high (Abd El-Halim et al., 2006).

The studies have also been made on the efficacy of cow urine in bee disease management Tiwari and Mall (2007), Aakash and Tiwari (2012) showed rapid recovery in disease infection within 8-10 days of cow urine spray with promotion of growth of bee brood. Other beneficial effects of cow urine on robbing, aggressiveness, egg laying and adult activities were also observed. It has been also observed that an ecto-parasitic mite in the honey bee colonies was controlled indirectly as the workers cleaned the brood area efficiently infested with the mite without killing them. It has also been noticed that the queen worked perfectly and laid eggs regularly after the spraying of cow urine in the infected honey bee colonies. Among the animal origin products i.e. cow urine, cow dung and cow dung ash powder and plant products i.e. ajwain powder @ 5g /hive showed the highest reduction in the mite brood infestation, increase in mite fall and sealed worker brood area without affecting the working tendency of worker bees, egg laying capacity of queen bee and newly laid eggs, brood and the bees. Among the natural plant products, ajwain powder (in comparison to synthetic thymol) can also be used in place of chemicals like sulphur, formic acid, thymol for mite disease management in honeybee colonies.

This was the novel approach to study about the effect of animal origin product, cow urine, plant decoctions and plant product i.e. ajwain powder against honeybee diseases in bee colonies in Uttarakhand. The present studies revealed that the animal origin products and ajwain powder can serve as a potential eco- friendly measure for management of mite diseases in honeybee colonies and can be suitable alternatives to conventional chemical materials such as thymol, formic acid, sulphur etc. and are safe, eco-friendly, readily available, almost free of cost to farmers and have long term effect without having any adverse effect on bees and hive products in Uttarakhand. Further studies are surely required to come to the final conclusions regarding the role of cow urine and its combination with plant extracts and use of natural thymol containing plant product, ajwain on the management of honeybee diseases in honey bee colonies at different locations of Uttarakhand. Thus, it may be concluded that animal and plant origin products are safe, eco-friendly, readily available, almost free of cost to farmers and have long term effect without having any adverse effect on bees and hive products.

\section{ACKNOWLEDGEMENTS}

Thanks are due to Director General, UCOST, Dehradun for funding the project entitled 
"Development of Eco- friendly Cow urine based Formulations for Honeybee disease management and Crop Protection in Uttarakhand". We extend thanks to Director Experimentation Station, Dean Agriculture and Head, Department of Entomology, College of Agriculture, Govind Ballabh Pant University of Agriculture and Technology, Pantnagar for providing necessary facilities for these investigations. Thanks are also due to the Successful Beekeepers, Shri Vikramjeet Singh (Happy), Sri Puran Chandra Joshi and Sri Pramod Garwal for extending necessary help to conduct experiments at their apiary sites.

\section{REFERENCES}

Aakash, C. and Tiwari, R. (2012). Efficacy of cow urine against bacterial disease, European foulbrood, in honey bee, Apis mellifera (L.) colonies at different locations of Uttarakhand-an eco-friendly and novel approach. International Journal of Basic and Applied Sciences, 1: 179-181.

Abd El-Halim, M. I., Ghoniemy, H.A. and Owayss, A.A. (2006). Combating honey bee Varroa mites by plant oils alone or in an IPM program. Plant Protection Department, Faculty of Agriculture, Fayoum, Egypt.. The 2nd conference of Farm Integrated Pest Management, 16-18 Jan., Faculty of Agriculture., Fayoum Univ., pp, 172-185.

Anderson, D.L. and Trueman, J.W.H.. (2000). Varroa jacobsoni (Acari: Varroidae) is more than one species. Experimental Application Acarology, 24: 165189.

Baxter, J., Eischen, F., Pettis, J., Wilson, W.T. and Shimanuki, H. (1998). Detection of fluvalinate-resistant Varroa mites in U.S. honey bees. American Bee Journal, 138: 291.

Chauzat, M. P., Faucon, J.P., Martel, A., Lachaize, J., Cougoule, N. and Aubert, M. (2006). A survey of pesticide residues in pollen loads collected by honey bees in France. Journal of Economic Entomology, 99: $253-262$.

De Jong, D. (1990). Mites: Varroa and other parasites of brood. Pp, 100-218 in R.A. Morse and R. Nowogrodzki, $e d s$. Honey bee pests, predators and diseases, $2^{\text {nd }}$ ed. Cornell University Press. Ithaca, New York.

Dhaliwal, G. S. and Singh, B. (2000). Pesticides and Environment Common Health, Publishers, New Delhi. pp, 439.

Dimetry, N.Z., Abd El-Waha, T.E. and Zakaria, M.E. (2005). Effective control of varroa mite Varroa destructor Anderson and Trueman infesting honey bee colonies Apis mellifera L. by some natural products. Bulletin of Faculty of Agriculture, 56: 295-308.

Elzen, P.J., Baxter, R., Elzen, G.W., Rivera, R. and Wilson, W. T. (2000). Evaluation of Grapefruit essential oils for controlling Varroa jacobsoni and Acarapis woodi. American Bee Journal, 140: 666-668.

Eischen, F.A. and Wilson, W.T. (1997). The effect of natural products smoke on Varroa jacobsoni. American Bee Journal, 137: 222-223.

Fathy, M. and Fouly, A.H.. (1995). The effect of some natural volatile oils to control the ectoparasitic mite Varroa jacobsoni infesting honey bee in Egypt. International Conference of Pest Control, Mansoura, Egypt, Sept. 1995, 311-318.

Harold, H., Wolfgang, R. and Elizabeth, Stephen, W.C. (1989). The control of parasitic bee mites: Varroa jacobsoni, Acarapis woodi and Tropilaelaps clareae with formic acid. American Bee Journal, 124: 739-752.

Henderson, C.F. and Tilton, W. (1955). Tests with Acaricides against the brown wheat mite. Journal of Economic Entomology, 48: 157-161.

Hu, D. and Coats, J. (2008). Evaluation of the environmental fate of thymol and phenethyl propionate in the laboratory. Pest Management Sciences, 64:775-779.

Imdorf, A., Bogdanov, S., Ochoa, R.I. and Calderone, N.W. (1999). Use of essential oils for control of Varroa jacobsoni (Oud.) in honey bee colonies. Apdiologie, 30: 209-228.

Khan M. S., Kumari, B., Rohilla, H. R., Kaushik, H. D. and Arora, R. K. (2004). Analysis of insecticide residues in honeys from apiary (Apis mellifera) and wild honey bee (Apis dorsata and Apis florea) colonies in India. Journal of Apiculture Research, 43(1): 45-49.

Milani, N. (2001) The resistance of Varroa jacobsoni (Oud.) to acaricides. Apidologie, 30: 229-234.

Miyagi, T., Peng, C. Y. S., Chuang, R.Y., Mussen, E.C., Spirak, M. S. and Doi, R. H. (2000). Verification of oxytetracycline resistant AFB pathogen in the United States. Journal of Invertebrate Pathology, 75: 95-96.

Sanjaram, B. and Rana, B.S. (2006). Control of European foulbrood diseases in Apis mellifera $\mathrm{L}$. colonies with antibiotics. Pest Management and Ecological Zoology, 11 (1): 31-36.

Shimanuki, H. and Knox, D.A. (1997). Summary of control methods. In Morse, R.A, Flottum, K. (eds) Honey bee pests, predators and diseases A.I. Root publishing. Medina, on USA, pp, 493-514.

Shoreit, M. N. and Hussein, M. H. (1994). Field trials for the control of varroa disease of honey bees by using coriander seeds extract. Zagazig Journal of Agricultaral Research, 21: 279-288.

Spreafico, M., Eördegh, F.R.., Bernardinelli, L. and Colombo, M.. (2001). First detection of strains of Varroa destructor resistant to Coumaphos: Results of laboratory test and field trials. Apidologie, 32: 49-55.

Tiwari, R. and Mall, P. (2007). An eco-friendly approach to manage European foulbrood disease of honey bee, Apis mellifera (L.) at Pantnagar. Journal of Eco-friendly Agriculture, 2: 201-203.

Wallner, K. (1999). Varroacides and their residues in bee products. Apidologie, 30: 235-248.

Williams, I. H. and Carreck, N. L. (1994). Land use changes and honey bee forage plants. In Forage for bees in an agricultural landscape (Ed. A. Matheson). International Bee Research Association, Cardiff. pp.7-20. 